\title{
Exploring Students and Lecturers Perceptions on Tablet Use for Learning in a South African Rural University
}

\author{
Simon Christopher Fernandez \\ Faculty of Science, Engineering and Technology, Walter Sisulu University, East London, South Africa
}

Received August 30, 2021; Revised October 21, 2021; Accepted November 11, 2021

\section{Cite This Paper in the following Citation Styles}

(a): [1] Simon Christopher Fernandez, "Exploring Students and Lecturers Perceptions on Tablet Use for Learning in a South African Rural University," Universal Journal of Educational Research, Vol. 9, No. 12, pp. 1928 - 1934, 2021. DOI: 10.13189/ujer.2021.091205.

(b): Simon Christopher Fernandez (2021). Exploring Students and Lecturers Perceptions on Tablet Use for Learning in a South African Rural University. Universal Journal of Educational Research, 9(12), 1928 - 1934. DOI: 10.13189/ujer.2021.091205.

Copyright $\bigcirc 2021$ by authors, all rights reserved. Authors agree that this article remains permanently open access under the terms of the Creative Commons Attribution License 4.0 International License

\begin{abstract}
Tablets are rapidly growing pervasive, influencing all age groups of people especially adolescents. Utilizing quantitative methodology, this study sought to explore the perceptions of students and lecturers on using tablets for learning at a rural university located in the Eastern Cape state of South Africa. A descriptive case study research design was employed. A sample of 155 from a population of 254 students and 14 from a population of 25 lecturers voluntarily participated in the survey. Data collected from the structured questionnaires were captured into Statistical Package for Social Sciences (version 24). Quantitative data were analysed using descriptive and inferential analysis. Data collected from both stakeholders were triangulated by sources to confirm the findings. The results revealed that students answered the exercise questions, developed the projects and started to search concepts in detail after getting tablets. Although a statistically significant difference was there between the perceptions of students and lecturers, both stakeholders showed positive attitudes toward the students' use of tablets for learning in university classrooms. The study recommended that lecturers must provide more tablet related learning tasks to students in order to make them accept tablet as a learning tool and lecturers must ensure regularly that those tasks are done effectively.
\end{abstract}

Keywords Tablet Computers, Learning, University, Educational Technology, Mobile Technology, Rural University Education, Lecturers Perceptions, Students Perceptions

\section{Introduction}

The past decade has witnessed the technological advancement of many digital gadgets such as tablet computers, smartphones and iPads. The rapid growth of these mobile technologies is influencing people in all fields especially in education [1]. Students are using these technologies for being online to perform mobile learning both inside and outside the classroom [2, 3]. More opportunities are formed for tertiary students to enhance their learning due to the growth of these mobile technologies [4]. Among all the mobile devices, tablet is the fastest development tool which has made an impact on education in the United States [5]. Students in higher education institutions are very quick in adopting tablets [6].

Despite tablets were made not for education, they have thrived to become an education tool [7] because of their ability to make a classroom paperless [8]. Many institutions around the world are purchasing a large quantity of tablets for the purpose of students learning [9]. As tablet is an inexpensive tool for engagement and collaboration, many universities all over the globe are integrating this device into their curriculum [10, 11].

Green et al. [6] conducted a study in Australian metropolitan university and found that students are bringing tablets to the university and they are using them 
for learning. Tablet enhances engagement between students and lecturers and improves the critical thinking and creativity of students [12]. It is an effective tool not only for the lecturers to prepare lectures and deliver presentations but also to have collaboration and active learning within the classroom among students [13].

There are investigations in which students used tablets for non-educational purposes too. A study conducted by Karalar and Sidekli [7] in Turkey showed that students used tablets for playing games, watching videos and used tablets to read eBooks rarely. A research conducted in Canada also showed that students had similar opinions. Even though they highlighted the positive sides, they did not fail to emphasize the distractions that were being caused by other students due to their non-educational use of tablets [14].

As indicated in the aforementioned literature, many universities all over the globe have integrated tablets in classroom and the majority of the former studies emphasized exclusively on the applications that are installed on tablets for learning $[15,16,17,18]$. It cannot be assured that learning applications on tablets will certainly make students use them for mobile learning [19]. Furthermore, the studies on students learning using tablets are inadequate $[19,15]$ especially in a developing country like South Africa that too from lecturers and students' perspectives. "As a key link between students and the institution, lecturers play a vital role in mediating students' expectations and learning experiences" [21, p. 47]. Lecturers play a vital role not only in steering the students on their use of tablets but also in permitting as well as preventing internet access using tablet $[22,23]$. Therefore, a detailed study is highly essential to examine the perspectives of lecturers and students on using tablets in the university classrooms. Moreover, the similar study is not popular in the Eastern Cape state of South Africa where the study was conducted. In the light of this, a study to collect and analyse the students' and lecturers' perspectives on tablet use for learning from a South African perspective is a pertinent problem that needs to be investigated.

The purpose of the study was to explore the perceptions of students and lecturers on using tablets for learning at a rural university located in the Eastern Cape State of South Africa. This study was guided by the following research question: How do students and lecturers vary in their perceptions on using tablet for university learning?

\subsection{Literature Review}

A very recent study was conducted by Narayan and Naidu [24] in the University of South Pacific to evaluate the students' usage of tablet computers for learning. A mixed method approach was adopted in that study. While 352 students participated in the survey, five students participated in the in-depth interview. Findings revealed that students were favourable towards the use of tablets in learning as it assisted them to access their learning materials very easily, engage and collaborate with their classmates as well as with their lecturers.

Percival and Claydon [14] were recognised to determine perceptions of the use of tablets by students both for their personal life and for education in the University of Ontario, Institute of Technology. A total of 50 students were selected randomly to participate in a survey that included both Likert scale and open ended qualitative questions. The result showed that participants were impressed with the portability of tablets, convenience to replace textbooks with tablets, easy ways to search study materials during class and particularly for taking notes. On the other hand, the students agreed that their primary usage with tablets was for entertainments specifically social networking and games which distracted other students in the classroom.

A study was conducted in an education college in South Western, United States to determine the lecturers' views on their use of technology (Tablets especially iPads) for educational purposes and their students' competency on technology. Utilizing qualitative method approach, eight faculty members were interviewed. A purposive sampling technique was employed in this study. Findings showed that almost all the participants indicated that their current students were technology competent and they were very quick and better at learning a new application than the former students. However, students also used their devices for off-task behaviours such as visiting social networking sites during class hours [25].

Similarly, another research was conducted in an American university where 115 teacher candidates participated in the online survey. The aim of the research was to assess the benefits and challenges they have faced and how tablets were used effectively for learning purposes. The questions in the online survey were based on their involvement and its impact of using tablets in their courses. Overall, they had positive experiences in using a variety of apps for different learning activities. They acquired more skills and knowledge through the use of tablets which made them more confident in their studies [26].

McBeth, Turley-Ames, Youngs, Ahola-Young and Brumfield [27] focused on the use of mobile technology in the classroom using tablets. They assessed 118 students who were enrolled in a tablet Pilot project which was sponsored by Idaho State University in the intermountain western United States. This project was started with an intention that students need exposure to technology as a collaborative device not to substitute but to compliment the interaction between humans. The web portal "Survey Monkey" was used for the survey, and the link was sent to the faculty to share with students. The researchers had observed a pedagogical challenge that a significant number of students who had the least exposure to technology were from the rural areas cannot find the importance of technology in their daily lives and were 
struggling to use the new technologies. Conversely, other groups of students reported that the use of tablets assisted them with multiple learning styles, enhanced their research skills, involvement in classroom and critical thinking.

A study was conducted to explore the university students' preferences and barriers to use tablet for learning. Using qualitative method approach, 20 students were interviewed and 343 students responded to the open-ended questionnaire. Findings showed that their preferred ways were to complete their academic tasks, to engage in online discussions, to search and learn through online platforms. Furthermore, their barriers were distraction, features of mobile device, limited support and resources [28].

A collective case study designed at St Mary's Health Care System in Athens Georgia sought to understand how tablets helped medical students in learning and adapting it in professional practice. Interviews and classroom observation were used in the data collection. Around 36 students of the third year participated in the study. As this study was an exploratory collective case that consisted of three stages and has finished only the first stage, the researcher had only initial data at this point and a long period of data collection had to be done in future. Preliminary findings showed that students were motivated and benefited from the use of technology. The majority of the medical students were using tablets to access the information of the patients when they were going for the rounds [29].

\section{Materials and Methods}

\subsection{Research Approach and Design}

The research adopted a quantitative approach and employed a descriptive case study research design.

\subsection{Study Site}

Data were collected from one of the campuses at a rural university located in the Eastern Cape state of South Africa. The justification for choosing this university as the study site was mainly due to the fact that at the time of data collection, only in this university tablets were offered to the students for learning purposes.

\subsection{Population and Sample}

A sample of 155 students ( 89 males; 66 females) from a population of 254 and another sample of 14 lecturers ( 9 males; 5 females) from a population of 25 voluntarily participated in the survey. Both stakeholder cohorts were selected from the departments of Information and Communication Technology and Electrical Engineering. All members of the sample were surveyed. Two separate questionnaires for each of the stakeholder cohorts provided the core data. The justification for choosing the participants from Information and Communication Technology and Electrical Engineering cohorts was purely based on the convenience of the researcher as he was also working in the same block in the same university.

\subsection{Data Collection Instrument}

Two 5-point Likert scale questionnaires were developed for each stakeholder cohort. Both questionnaires were comprised of two sections in which the first section included the demographic questions and the second section included six questions on the perceptions of students and lecturers on using tablets for university learning. The scale has five levels in which level 1 being "STRONGLY DISAGREE", level 2 being "DISAGREE", level 3 being "NO OPINION", level 4 being "AGREE" and level 5 being "STRONGLY AGREE". Some of the items in the questionnaire used by Agir [30] in his study were modified and used in this research.

\subsection{Validity and Reliability}

Pilot studies were conducted with five students and five lecturers separately who were not part of the main study to measure the validity of the questionnaire. The response received from the pilot study made the Likert-scale questionnaire more perfect. As it was a scale with items less than 10, mean inter-item correlation was calculated to test the internal consistency of the scale for students and lecturers and found to be 0.5 and 0.154 respectively. Mean inter-item correlation value between 0.15 to 0.5 can be considered as an optimal result [31].

\subsection{Ethical Compliances}

Ethical clearance was obtained from the concerned authorities to collect and analyse the data. Signed consent forms were obtained from all the participants before the commencement of the data collection.

\subsection{Data Collection Procedure and Data Analysis}

The students' questionnaire in the main study was administered by a few academic colleagues of the researcher to make the data bias less. The researcher visited the classrooms before the commencement of administering the questionnaire and explained to the students about this study and the consent form. Although all information was there in the consent form, the researcher still informed them that their participation would be voluntary and their responses would be confidential and anonymous. The questionnaire for lecturers was emailed and reminders were sent to them in the form of WhatsApp and personal messages. While the response rate of students was $100 \%$, response rate of lecturers was only $56 \%$. The data were collected from both stakeholders at the end of 2017. The researcher captured the data manually into Statistical Package for Social Sciences (SPSS version 24) and they were analysed 
using descriptive and inferential statistics. Data collected from both stakeholders were triangulated by sources to confirm the findings. Categorical variables of the surveyed data were compared and tested using the Independent Samples t-test to compute frequency tables and descriptive statistics. A p-value $<0.05$ was considered to be statistically significant.

\section{Results}

It can be seen that $31.8 \%$ of the students strongly disagreed and $23.6 \%$ of them disagreed that they started to solve puzzle kind of exercises after getting tablet (item S1). Around $31.8 \%$ of the students agreed and $12.8 \%$ of them strongly agreed on item S1. About seven students did not answer. While $15.3 \%$ of the lecturers disagreed on item L1, more than half $(53.9 \%)$ of the lecturers were uncertain. Around $23 \%$ of the lecturers agreed and $7.8 \%$ of them strongly agreed on item L1 and only one lecturer did not answer.

It was observed that $13.4 \%$ of the students strongly disagreed and $38.3 \%$ of them disagreed that they started to create presentations in class after getting tablet (item S2). About $30.9 \%$ of the students agreed and $17.4 \%$ of them strongly agreed on item S2. Around six students did not attend item S2. While $7.1 \%$ of the lecturers disagreed on item L2, 28.7\% of them were uncertain. About $57.1 \%$ of the lecturers agreed and $7.1 \%$ of them strongly agreed on item L2.

Around $12 \%$ of the students strongly disagreed and $18.1 \%$ of them disagreed on item S3 that they started to do homework. More than one-third (38.2\%) of students agreed and $31.7 \%$ of them strongly agreed on item S3. About six students did not answer item S3. On the other hand, $7.1 \%$ of the lecturers disagreed on item L3 and 50\% of them did not have any opinion. Approximately 35.8\% of them agreed and $7.1 \%$ of them strongly agreed on item L3.

Out of 148 students who answered item S4, 10.1\% of the students strongly disagreed and $25 \%$ of them disagreed that they started to answer the exercise questions. About $35.9 \%$ of the students agreed and $29 \%$ of them strongly agreed on item S4. Furthermore, seven students did not answer item S4. Around $21.4 \%$ of the lecturers disagreed and $28.6 \%$ of them were indeterminate on item L4. While $42.9 \%$ of lecturers agreed, $7.1 \%$ of them strongly agreed on item L4.

While $21 \%$ of the students strongly disagreed and $27.9 \%$ of them disagreed that they started to develop projects after getting tablet (item S5), 28.7\% of the students agreed and $22.4 \%$ of them strongly agreed on item S5. Around eight students did not answer item S5. On the other hand, while $28.6 \%$ of the lecturers disagreed on item L5, 21.4\% of lecturers agreed and another $21.4 \%$ of them strongly agreed on item S6. About $28.6 \%$ of the lecturers were indeterminate.

Furthermore, it was observed that $12.2 \%$ of the students strongly disagreed and $27.2 \%$ of them disagreed that they started to search concepts in detail (item S6). Around 37.5\% of the students agreed and $23.1 \%$ of them strongly agreed on item S6. About eight students did not attend item S6. While a minority of the lecturers (8.3\%) disagreed on item L6, half of the lecturers (50\%) agreed and $16.7 \%$ of them strongly agreed on item L6. One quarter of the lecturers $(25 \%)$ did not have any opinion.

Table 1. Triangulation of Students and Lecturers perception on students' use of tablets for learning in rural university classrooms

\begin{tabular}{|c|c|c|c|c|c|c|c|c|}
\hline \# & ITEMS & SD & D & NO & $\mathbf{A}$ & SA & $\mathbf{N}$ & NA \\
\hline S1 & $\begin{array}{l}\text { After getting tablet, I started to solve puzzle } \\
\text { kind of exercises. }\end{array}$ & $\begin{array}{c}47 \\
(31.8 \%)\end{array}$ & $\begin{array}{c}35 \\
(23.6 \%)\end{array}$ & $\begin{array}{c}0 \\
(0 \%)\end{array}$ & $\begin{array}{c}47 \\
(31.8 \%)\end{array}$ & $\begin{array}{c}19 \\
(12.8 \%)\end{array}$ & $\begin{array}{c}148 \\
(100 \%)\end{array}$ & 7 \\
\hline L1 & $\begin{array}{l}\text { After getting tablet, students started to solve } \\
\text { puzzle kind of exercises. }\end{array}$ & $\begin{array}{c}0 \\
(0 \%) \\
\end{array}$ & $\begin{array}{c}2 \\
(15.3 \%) \\
\end{array}$ & $\begin{array}{c}7 \\
(53.9 \%) \\
\end{array}$ & $\begin{array}{c}3 \\
(23 \%) \\
\end{array}$ & $\begin{array}{c}1 \\
(7.8 \%) \\
\end{array}$ & $\begin{array}{c}13 \\
(100 \%) \\
\end{array}$ & 1 \\
\hline S2 & $\begin{array}{c}\text { After getting tablet, I started to create } \\
\text { presentations in class. }\end{array}$ & $\begin{array}{c}20 \\
(13.4 \%)\end{array}$ & $\begin{array}{c}57 \\
(38.3 \%) \\
\end{array}$ & $\begin{array}{c}0 \\
(0 \%)\end{array}$ & $\begin{array}{c}46 \\
(30.9 \%) \\
\end{array}$ & $\begin{array}{c}26 \\
(17.4 \%)\end{array}$ & $\begin{array}{c}149 \\
(100 \%)\end{array}$ & 6 \\
\hline L2 & $\begin{array}{l}\text { After getting tablet, students started to create } \\
\text { presentations in class. }\end{array}$ & $\begin{array}{c}0 \\
(0 \%)\end{array}$ & $\begin{array}{c}1 \\
(7.1 \%)\end{array}$ & $\begin{array}{c}4 \\
(28.7 \%)\end{array}$ & $\begin{array}{c}8 \\
(57.1 \%)\end{array}$ & $\begin{array}{c}1 \\
(7.1 \%)\end{array}$ & $\begin{array}{c}14 \\
(100 \%)\end{array}$ & 0 \\
\hline S3 & After getting tablet, I started to do homework. & $\begin{array}{c}18 \\
(12 \%)\end{array}$ & $\begin{array}{c}27 \\
(18.1 \%)\end{array}$ & $\begin{array}{c}0 \\
(0 \%)\end{array}$ & $\begin{array}{c}57 \\
(38.2 \%)\end{array}$ & $\begin{array}{c}47 \\
(31.7 \%)\end{array}$ & $\begin{array}{c}149 \\
(100 \%)\end{array}$ & 6 \\
\hline L3 & $\begin{array}{l}\text { After getting tablet, students started to do } \\
\text { homework. }\end{array}$ & $\begin{array}{c}0 \\
(0 \%) \\
\end{array}$ & $\begin{array}{c}1 \\
(7.1 \%)\end{array}$ & $\begin{array}{c}7 \\
(50 \%) \\
\end{array}$ & $\begin{array}{c}5 \\
(35.8 \%) \\
\end{array}$ & $\begin{array}{c}1 \\
(7.1 \%)\end{array}$ & $\begin{array}{c}14 \\
(100 \%)\end{array}$ & 0 \\
\hline S4 & $\begin{array}{l}\text { After getting tablet, I started to answer } \\
\text { exercise questions. }\end{array}$ & $\begin{array}{c}15 \\
(10.1 \%)\end{array}$ & $\begin{array}{c}37 \\
(25 \%)\end{array}$ & $\begin{array}{c}0 \\
(0 \%)\end{array}$ & $\begin{array}{c}53 \\
(35.9 \%) \\
\end{array}$ & $\begin{array}{c}43 \\
(29 \%)\end{array}$ & $\begin{array}{c}148 \\
(100 \%)\end{array}$ & 7 \\
\hline L4 & $\begin{array}{l}\text { After getting tablet, students started to answer } \\
\text { exercise questions. }\end{array}$ & $\begin{array}{c}0 \\
(0 \%)\end{array}$ & $\begin{array}{c}3 \\
(21.4 \%)\end{array}$ & $\begin{array}{c}4 \\
(28.6 \%)\end{array}$ & $\begin{array}{c}6 \\
(42.9 \%)\end{array}$ & $\begin{array}{c}1 \\
(7.1 \%) \\
\end{array}$ & $\begin{array}{c}14 \\
(100 \%)\end{array}$ & 0 \\
\hline S5 & $\begin{array}{c}\text { After getting tablet, I started to develop the } \\
\text { project. }\end{array}$ & $\begin{array}{c}31 \\
(21 \%) \\
\end{array}$ & $\begin{array}{c}41 \\
(27.9 \%)\end{array}$ & $\begin{array}{c}0 \\
(0 \%)\end{array}$ & $\begin{array}{c}42 \\
(28.7 \%)\end{array}$ & $\begin{array}{c}33 \\
(22.4 \%)\end{array}$ & $\begin{array}{c}147 \\
(100 \%)\end{array}$ & 8 \\
\hline L5 & $\begin{array}{l}\text { After getting tablet, students started to } \\
\text { develop the project. }\end{array}$ & $\begin{array}{c}0 \\
(0 \%)\end{array}$ & $\begin{array}{c}4 \\
(28.6 \%)\end{array}$ & $\begin{array}{c}4 \\
(28.6 \%)\end{array}$ & $\begin{array}{c}3 \\
(21.4 \%)\end{array}$ & $\begin{array}{c}3 \\
(21.4 \%)\end{array}$ & $\begin{array}{c}14 \\
(100 \%)\end{array}$ & 0 \\
\hline S6 & $\begin{array}{l}\text { After getting tablet, I started to search } \\
\text { concepts in detail. }\end{array}$ & $\begin{array}{c}18 \\
(12.2 \%)\end{array}$ & $\begin{array}{c}40 \\
(27.2 \%)\end{array}$ & $\begin{array}{c}0 \\
(0 \%)\end{array}$ & $\begin{array}{c}55 \\
(37.5 \%)\end{array}$ & $\begin{array}{c}34 \\
(23.1 \%)\end{array}$ & $\begin{array}{c}147 \\
(100 \%)\end{array}$ & 8 \\
\hline L6 & $\begin{array}{l}\text { After getting tablet, students started to search } \\
\text { concepts in detail. }\end{array}$ & $\begin{array}{c}0 \\
(0 \%)\end{array}$ & $\begin{array}{c}1 \\
(8.3 \%)\end{array}$ & $\begin{array}{c}3 \\
(25 \%)\end{array}$ & $\begin{array}{c}6 \\
(50 \%)\end{array}$ & $\begin{array}{c}2 \\
(16.7 \%)\end{array}$ & $\begin{array}{c}12 \\
(100 \%)\end{array}$ & 2 \\
\hline
\end{tabular}

Note. $\#=$ item number, $\mathrm{S}=$ Student, $\mathrm{L}=$ Lecturer, $\mathrm{SD}=$ Strongly Disagree, $\mathrm{D}=$ Disagree, $\mathrm{NO}=\mathrm{No}$ opinion, $\mathrm{A}=\mathrm{Agree}, \mathrm{SA}=\mathrm{Strongly}$ Agree and $\mathrm{N}$ $=$ Total Answered. 
Table 2. Independent Samples t-test

\begin{tabular}{|c|c|c|c|c|c|c|c|c|c|c|}
\hline \multicolumn{11}{|c|}{ Independent Samples Test } \\
\hline & & \multicolumn{2}{|c|}{$\begin{array}{l}\text { Levene's Test for } \\
\text { Equality of Variances }\end{array}$} & \multicolumn{7}{|c|}{ t-test for Equality of Means } \\
\hline & & \multirow[t]{2}{*}{$\mathrm{F}$} & \multirow[t]{2}{*}{ Sig. } & \multirow[t]{2}{*}{$\mathrm{t}$} & \multirow[t]{2}{*}{$\mathrm{df}$} & \multirow[t]{2}{*}{$\begin{array}{c}\text { Sig. } \\
\text { (2-tailed) }\end{array}$} & \multirow[t]{2}{*}{$\begin{array}{c}\text { Mean } \\
\text { Difference }\end{array}$} & \multirow[t]{2}{*}{$\begin{array}{l}\text { Std. Error } \\
\text { Difference }\end{array}$} & \multicolumn{2}{|c|}{$\begin{array}{c}95 \% \text { Confidence } \\
\text { Interval of the } \\
\text { Difference }\end{array}$} \\
\hline & & & & & & & & & Lower & Upper \\
\hline \multirow{2}{*}{$\begin{array}{c}\text { TOTALSC } \\
\text { ORES }\end{array}$} & $\begin{array}{c}\text { Equal variances } \\
\text { assumed }\end{array}$ & .000 & .983 & -4.007 & 167 & .000 & -4.813 & 1.201 & -7.184 & -2.442 \\
\hline & $\begin{array}{c}\text { Equal variances not } \\
\text { assumed }\end{array}$ & & & -3.816 & 15.166 & .002 & -4.813 & 1.261 & -7.499 & -2.127 \\
\hline
\end{tabular}

An independent samples t-test was conducted to compare the perceptions of students and lecturers at a 5\% level of significance (i.e., $\alpha=0.05$ ). There was a statistically significant difference in perceptions of students $(M=15.19 ; S D=4.283)$ and lecturers $(M=20.00$; $S D=4.540 ; t(167)=-4.007)$. The observed p-value (2-tailed) was 0.000 which is less than the level of significance (0.05). The magnitude of the differences in the means was -4.813 with $95 \%$ CI: -7.184 to 2.442 . Therefore, the results show that perceptions of students and lecturers are not the same on using tablets for university learning.

\section{Discussion}

The majority of the students did not solve puzzle kind of exercises after getting tablets. However, many of the lecturers were uncertain. McBeth et al. [27] averred that only a minority of the students used tablets to solve puzzles. Jain [32] conducted a study on how the use of Information and Communication Technology (ICT) elements can be used in teaching English literature and excite students and academics to bridge the digital divide. Jain [32] stated that literacy criticism or literary studies using ICT will be interesting through practical exercises. Therefore, although the findings of the current study obtained from students are stable with the perceptions of McBeth et al. [27], oppose to perceptions of Jain [32]. As per the view of researcher, this discrepancy between the perception of students and lecturers could be because lecturers may be insisting the students to do the puzzle kind of exercises to develop their level of concentration and skills such as critical thinking and problem solving and thereafter lecturers may not be checking whether they are solving them or not. Students know that lecturers usually do not check these exercises of students which may lead students to have less interest in solving puzzle kind of exercises.

Despite lecturers assert that students used tablets for the purpose of presentations, students had a different opinion that they did not use tablets to create presentations in class. Students' perception is parallel with the results by Agir
[30] who stated that "students do not prefer to use the iPad for making presentations". However, lecturers' perception contradicts with the findings by Agir [30] and is stable with the results of Henderson [33] who stated that academics integrated digital technologies in the learning and teaching to reduce the digital divide and students were competent well to prepare the PowerPoint presentation and execute the task. Lecturers know that using tablet for presentations is a vital skill that every student should possess as it helps them to have confidence in their subject. Students' current perception may change when they create more presentations in class using tablets.

While the majority of the students agreed that they have started doing homework after getting tablets, most of the lecturers were uncertain. Gong and Wallace [34] indicated that students were using tablets to search for information for doing homework. Dundar and Akcayir [35] also supported the fact that tablets aid students to do the homework. A study conducted by Mendicino, Razzaq and Heffernan [36] suggested that as the digital divide contracts, the openings for the students to do their homework widens. The perception of students is similar to the findings by Gong and Wallace [34], Dundar and Akcayir [35] and Mendicino, Razzaq and Heffernan [36]. According to the researcher of the current study, lecturers' uncertainty shows that they are not checking whether students are doing the homework or not. Usage of tablets to do homework helped to narrow down the digital divide among students.

The study revealed that both stakeholders had a common opinion that students started to answer exercise questions after getting tablets. This is in parallel with the results of Enriquez [37] who affirmed that students used tablets to solve the exercises which were given by their lecturers at the end of each lecture. The researcher of the current study views that it will be always convenient for the students to submit their answers and lecturers to examine students' submitted work.

The result found from the present study showed that after getting tablets, students started to develop their projects. Kozma, McGhee, Quellmalz and Zalles [38] conducted a study to close the digital divide between developed and developing countries on their use of 
computers to prepare students for the global workforce. They found that students gained skills by engaging in activities such as collecting data for research and student collaboration for the research projects. The finding of this study is stable with the findings by Kozma, McGhee, Quellmalz and Zalles [38] and Agir [30] who indicated that students used their tablets to work on projects with their classmates. As tablets are easy to handle, it will also be convenient for the students to develop their projects as and when they require.

The study established that students preferred to use their tablets for searching the concepts in detail. Pagan, Martinez and Maiquez [39] conducted a study on the digital divide in viable forms of development for education and found that majority of the students felt internet technology as a useful tool to search and access the information. McBeth et al. [27] also obtained a similar finding that the majority of students used their tablets to discover and explore the educational concepts. Students can explore each and every concept in detail from anywhere and at any time by searching in the internet using tablet.

\section{Conclusions}

The study could be concluded from the findings that both students and lecturers showed positive attitudes on students' use of tablets for learning in rural university classrooms. Students answered the exercise questions, developed the projects and started to search concepts in detail using tablets. However, there was a statistically significant difference between the perceptions of students and lecturers.

Among three limitations, first and foremost is the size of the lecturers who participated in the survey was only 14 . Secondly, both stakeholders were selected only from the departments of Information and Communication Technology and Electrical Engineering. It would have been better if more lecturers were included in this study from other departments as well to know their perception which would also help to increase the sample size. Finally, the number of survey items used in the study was only six. It would have offered a broad examination if there were some more items.

The study recommended that lecturers must provide more tablet related learning tasks to students in order to make them accept tablet as a learning tool and lecturers must ensure regularly that those tasks are done effectively on time.

The results of this study are expected to stimulate further research on other areas such as a comparison between students' use of tablets in university and students' use of tablets in school.

\section{REFERENCES}

[1] McCoy B. R., "Digital Distractions in the Classroom: Student Classroom Use of Digital Devices for Non-Class Related Purposes," Journal of Media Education, vol. 4, no.4, pp. 5-32, 2013. https://digitalcommons.unl.edu/cgi/viewco ntent.cgi? article $=1091 \&$ context $=$ journalismfacpub

[2] Menkhoff T., Bengtsson M. L., "Engaging students in higher education through mobile learning: lessons learnt in a Chinese entrepreneurship course," Educational Research for Policy and Practice, vol. 11, no. 3, pp. 225-242, 2012. DOI: $10.1007 / \mathrm{s} 10671-011-9123-8$.

[3] Johnson L., Adams S., Cummins M., "Mobile apps. The NMC horizon report: 2012 higher education edition," The new media consortium, Austin, Texas, 2012.

[4] Mang C. F., Wardley L. J., "Effective Adoption of Tablets in Post-Secondary Education: Recommendations Based on a Trial of tablets in University Classes," Journal of Information Technology Education, vol. 11, pp. 301-317, 2012. https://www.learntechlib.org/p/71156/

[5] Poll H., "Pearson student mobile device survey 2015", http://www.pearsoned.com/wp-content/uploads/2015-Pear son-Student-Mobile-Device-Survey-College.pdf (accessed March. 28, 2021).

[6] Green D., Naidoo E., Olminkhof C., Dyson L. E., "Tablets@university: The ownership and use of tablet devices by students," Australasian Journal of Educational Technology, vol. 32, no. 3, pp. 50-64, 2016. https://doi.org/10.14742/ajet.2195.

[7] Karalar H., Sidekli S., "How Do Second Grade Students in Primary Schools Use and Perceive Tablets?," Universal Journal of Educational Research, vol. 5, no. 6, pp. 965-971, 2017. DOI: $10.13189 /$ ujer.2017.050609.

[8] Haßler B., Major L., Hennessy S., "Tablet use in schools: A critical review of the evidence for learning outcomes," Journal of Computer Assisted Learning, vol. 32, no.2, pp. 139-156, 2016. DOI:10.1111/jcal.12123.

[9] Vu P., McIntyre J., Cepero J., "Teachers' Use of the tablet in Classrooms and Their Attitudes toward Using It," Journal of Global Literacies, Technologies, and Emerging Pedagogies, vol. 2, no. 2, pp. 58-76, 2014.

[10] Foresman C., "The tablet goes to college this fall", cnn, http://edition.cnn.com/2010/TECH/mobile/07/26/tablet.uni versity.ars/index.html (accessed March. 28, 2021).

[11] Miller W., "iTeaching and Learning Collegiate Instruction Incorporating Mobile Tablets," Library Technology Reports, vol. 48, no. 8, pp. 54-59, 2012. DOI:10.5860/1tr.48n8.

[12] Goral T., "Take II Tablets,” University Business, pp.46-49, 2011.

[13] Mock K., "Teaching with Tablet PC's," Journal of Computing Sciences in Colleges, vol. 20, pp. 17-27, 2004.

[14] Percival J., Claydon T., "A study of student and instructor perceptions of tablet PCs in higher education contexts," Proceedings of the Higher Education in Transformation Conference, Dublin, Ireland, 2015, pp. 250-264. https:/arrow.tudublin.ie/st3/9/ 
[15] Zakaria W. N. W., Abas H., Masrom M., Mohdali R., Mohamed N. N. N., "Development of self-learning economics app for secondary school students in Malaysia based on information processing model," TEM J., vol. 8, no. 3, pp. 908-914, 2019, DOI: 10.18421/TEM83- 31.

[16] Demir K., Akpınar E., "The effect of mobile learning applications on students' academic achievement and attitudes toward mobile learning," Malaysian Online Journal of Educational Technology, vol. 6, no. 2, 2018. DOI: 10.17220/mojet.2018.02.004.

[17] Zhang, S., "Mobile english learning: An empirical study on an APP, English Fun Dubbing," Int. J. Emerg. Technol. Learn., pp. 4-8, 2016. DOI: 10.3991/ijet.v11i12.6314.

[18] Zydney, J. M., Warner Z., "Mobile apps for science learning: Review of research," Computers \& Education, 94, 2016, DOI: 10.1016/j.compedu.2015.11.001.

[19] Fazamin A., Yusoff M., Ismail I., Yacob A., "The Behavioural Intentions of Secondary School Students to Use Tablet as a Mobile Learning Device," International Journal of Interactive Mobile Technologies (iJIM), vol. 14, no. 13, pp. 161-171, 2020. DOI: 10.3991/ijim.v14i13.13027.

[20] Wakefield J., Frawley J.K., Tyler J., Dyson L.E., "The impact of an iPad supported annotation and sharing technology on university students' learning,". Computers \& Education, vol. 122, pp. 243-259, 2018. DOI: 10.1016/j.compedu.2018.03.013.

[21] DHET, "STUDENTS' ACCESS TO AND USE OF LEARNING MATERIALS Survey Report 2020,” 2020. https://www.usaf.ac.za/wp-content/uploads/2021/02/DHE T_SAULM-Report-2020.pdf

[22] Wood E., Petkovski M., De Pasquale D., Gottardo A., Evans M. A., Savage R. S., "Parent scaffolding of young children when engaged with mobile technology," Frontiers in Psychology, vol. 7, no. 690, 2016. DOI: 10.3389/fpsyg.2016.00690.

[23] Marsh J., "Russian dolls and three forms of capital: Ecological and sociological perspectives on parent's engagement with young children's tablet use, "in The Case of the iPad: Mobile Literacies in Education, Springer, 2017, pp. 31-47. DOI: 10.1007/978-981-10-4364-2_3.

[24] Narayan S., Naidu S., "What do you with your tablet computer? Undergraduate student's perceptions of tablet computers and its use in their learning at the University of the South Pacific," Asian Journal of distance Education, vol 15, no. 1, pp. 219-243, 2020. DOI: 10.5281/zenodo.3891789.

[25] Islim O. F., Cirak N. S., "Technology and College Students: What Faculty Members Think About the Use of Technology in Higher Education," Malaysian Online Journal of Educational Technology, vol. 5, no. 2, pp. 51-67, 2017.

[26] Shen Y. W., "An evaluation of the impact of using tablets in teacher education," The Online Journal of New Horizons in Education, vol. 6, no. 4, pp. 18-25, 2016. https://www.tojned.net/journals/tojned/articles/v06i04/v06i 04-02.pdf
[27] McBeth M. K., Turley-Ames K., Youngs Y., Ahola-Young L., Brumfield A., "The iPad Pilot Project: A Faculty Driven Effort to Use Mobile Technology in the Reinvention of the Liberal Arts," Journal of Teaching and Learning with Technology, vol. 4, no. 1, pp. 1-21, 2015. DOI: 10.14434/jotlt.v4n1.13216.

[28] Alomary A., Woollard J., "Exploring Preferences and Barriers in Learning with Tablet Computers by University Students," International Journal of Management and Applied Science, vol. 3, no. 8, pp. 10-14, 2017.

[29] Hill J., Nuss M., Middendorf B., Cervero R., Gaines J., "Using tablets to Enhance Teaching and Learning in Third-Year Medical Clerkships," Proceedings of E-Learn: World Conference on E-Learning in Corporate, Government, Healthcare, and Higher Education, Chesapeake, VA, 2012, pp. 1482-1488.

[30] Agir A., "iPad at School: A Holistic Evaluation of the Opinions of Students, Teachers and Parents concerning iPad Use," International Journal of Education, vol. 7, no. 3, pp. 175-193, 2015. DOI: 10.5296/ije.v7i3.7924.

[31] Clark A., Watson D., "Constructing validity: Basic issues in objective scale development," Psychological Assessment, vol. 7, pp. 309-319, 1995. DOI: 10.1037/1040-3590.7.3.30 9.

[32] Jain M., "ICT as an Aid in Teaching English Literature and Bridging the Digital Divide," Bhatter College Journal of Multidisciplinary Studies, vol. 2, pp. 49-54, 2012.

[33] Henderson R., "Classroom pedagogies, digital literacies and the home-school digital divide," International Journal of Pedagogies and Learning, vol. 6, no. 2, pp. 152-161, 2011. DOI: $10.5172 /$ ijpl.2011.152.

[34] Gong Z., Wallace J. D., “A comparative analysis of iPad and other M-learning technologies: exploring students' view of adoption, potentials, and challenges," Journal of Literacy and Technology, vol. 13, no. 1, pp. 2-29, 2012.

[35] Dundar H., Akcayir M., "Implementing tablet PCs in schools: Students' attitudes and opinions," Computers in Human Behavior, vol. 32, pp. 40-46, 2014. DOI: 10.1016/j.chb.2013.11.020.

[36] Mendicino M., Razzaq L., Heffernan N. T., “A Comparison of Traditional Homework to Computer-Supported Homework," Journal of Research on Technology in Education, 41(3), 331-359, 2014. DOI: 10.1080/15391523 .2009.10782534.

[37] Enriquez A. G., "Enhancing Student Performance Using Tablet Computers," College Teaching, vol .58, no. 3, pp. 77-84, 2010. DOI: 10.1080/87567550903263859.

[38] Kozma R., McGhee R., Quellmalz E., Zalles D., "Closing the digital divide: evaluation of the World Links program," International Journal of Educational Development, vol. 24, no. 4, pp. 361-381, 2004. DOI:10.1016/j.ijedudev.2003.11. 014.

[39] Pagan F. J. B., Martinez J. L., Maiquez M. C. C., "Internet Use by Secondary School Students: A Digital Divide in Sustainable Societies?," Sustainability, vol. 10, no. 10, 3703, 2018. DOI: 10.3390/su10103703. 